\title{
Certain aspects concerning the development of a functioning scheme of the auto-mated system to control energy flows of underground iron-ore enterprises
}

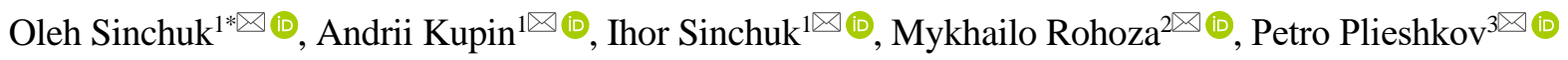 \\ ${ }^{l}$ Kryvyi Rih National University, Kryvyi Rih, 50027, Ukraine \\ ${ }^{2}$ Dnipro University of Technology, Dnipro, 49005, Ukraine \\ ${ }^{3}$ Central Ukrainian National Technical University, Kropyvnytskyi, 25006, Ukraine \\ *Corresponding author: e-mail speet@ukr.net, tel. +380963876559
}

\begin{abstract}
Purpose is to develop a functioning scheme of ACS for energy flows in terms of invariability of electric power consumption as well as inversion of energy flows of mining enterprises in the current time of day to decrease power cost segment in the context of epy prime cost of iron ore raw materials (IORM) extraction.

Methods. Data of a passive experiment have been applied to obtain operational statistics of iron-ore mines. Then fuzzy logic has been applied to identify linguistic terms on the required technological parameters; and procedures of fuzzification, logical derivation and defuzzification have been performed. Principles to form basis of fuzzy rules have been determined to enable decision-making automation using Mamdani method. As a result, fuzzy controllers have been synthesized; and their performance has been modeled in the environment of a software package MatLab. The basic modeling results have been visualized using MS Excel.
\end{abstract}

Findings. System of control criteria system has been substantiated; and vectors of an object condition vector, the basic information parameters, controlling influence and disturbances have been defined. Approaches to optimize power consumption process basing upon epy minimax functionals, use of restriction system, and calculation of rational settings have been analyzed. Algorithms of the automated control have been developed using several strategies and criteria. Implementation principles of the algorithm have been proposed on the basis of fuzzy logic use.

Originality. Efficiency of fuzzy systems to control energy flows of mines has been proved under the conditions of one- and multi-channel regulating process. The basic analytical indices have been obtained supporting unambiguously both sufficient quality and efficiency of the automated control systems to be used for underground mining of iron ore.

Practical implications. Structural patterns and means of practical implementation of fuzzy controllers have been proposed for industrial environment application. Calculations have proved that the approaches will help implement the automated control of energy consumption by a mine in real time, and optimize expenditures connected with the consumed electric energy.

Keywords: automated control of energy flows, fuzzy logic, control system, three-zone tariff

\section{Introduction}

Mining and smelting industry is the basic component of macroeconomy of the industry-oriented world countries. In turn, almost $60 \%$ of annual currency returns to treasury of Ukraine are provided by iron-ore enterprises of the branch.

More than $30 \%$ of high-grade iron ore raw materials (IORM) of the country are extracted by means of underground mining methods [1].

For a number of objective reasons and artificially created ones, during the last decades, prime cost of domestic IORM extraction has demonstrated stable and negative for Ukraine tendency towards annual growth. At the same time, for a number of reasons the world materials market reduces prices for the type of minerals [2]. Mining and smelting enterprises enter a stage of a depressive development. The fact poses risk to the functioning of iron-ore enterprises manufacturing the product type.

Analysis of segments of IORM extraction elements using underground and combined (i.e. surface and underground) methods has shown that more than $20 \%$ of the total levels of the system of prime cost of the minerals are energy consumption. In turn, more than $90 \%$ of them are electricity bills (Fig. 1) [3].

Intrinsically, the message is trivial since it is common knowledge that mining enterprises on the whole as well as their subtype (i.e. ore-mining ones) are models of the most energy-intensive branches [4]. 


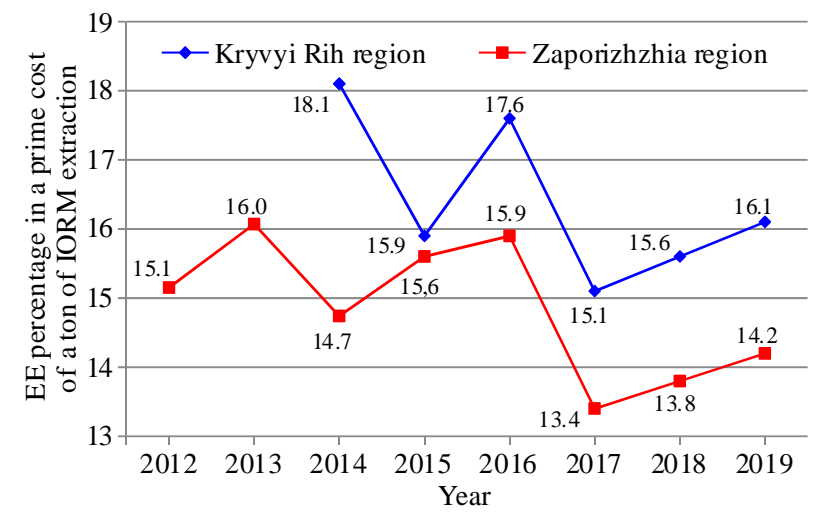

Figure 1. Indices of electric energy levels in the context of the total cost of iron ore raw materials extraction in the mines of Kryvyi Rih and Zaporizhzhia regions

It should be noted as an important fact that in future a level of energy intensity of ore-mining enterprises will demonstrate its growth since at the operating production units, IORM mining depth experiences constant increase. In the context of underground mining it has exceeded $1500 \mathrm{~m}$ which was the boundary predicted by projects.

In the near future, mining depth in iron-ore mines will achieve $2000 \mathrm{~m} \mathrm{[1].} \mathrm{To} \mathrm{an} \mathrm{even} \mathrm{greater} \mathrm{degree,} \mathrm{the} \mathrm{fact} \mathrm{will}$ complicate both "power industry" and economy of iron ore enterprises on the whole. Even sadder news for iron ore industry is the stable price increase in the consumed electric energy (EE). It should be added that adoption of the law of Ukraine "On the market of electric energy" [5] is far from being optimistic as for the mitigation of load on the national mining enterprises.

The abovementioned poses risks to competitiveness of our iron-ore enterprises in the world market of raw materials. In other words, in its essence, the problem to improve power efficiency of industrial organizations is the "National Project" for Ukraine as well as for the majority of countries. Moreover, it is among the problems being under active global analysis for the last decades.

Over and over again, economic situation in the mining industry of Ukraine emphasizes the extremely important idea of the necessity and urgency of further search for ways to improve power efficiency and reduce energy intensity of IORM extraction. Implementation complexity of the project is as follows: it is a problem to decrease EE consumption under the conditions of the available mining methods. Furthermore, the lower mining is, the greater EE consumption becomes. Thus, not ignoring the importance of other measures, a problem of EE consumption redistribution comes to the fore. The redistribution should be implemented inside the enterprise among energy-intensive consumers forming maxima of the consumption.

Search for the problem solving is on the agenda throughout a cycle of EE implementation in the functioning technology of the enterprises. The fact is also "favoured" by constant price pressure on enterprises, consuming EE, by power generating companies. Target criterion of the approach is a price-oriented policy of power generating companies as well as power distributing ones while forming prices for the energy which has been generated. Logical response to the approach should be as follows: the enterprises, consuming the $\mathrm{EE}$, have to take appropriate measures to improve the effi- ciency of EE consumption while mitigating material pressure of a power sector on the level of formation of prime cost of IORM extraction.

\section{Methods}

Theoretically, a number of studies have substantiated "in a frame manner" the aspects to improve energy efficiency of iron-ore enterprises and formatized them [6]-[9]. Generalizing conclusions, concerning the available tendencies to improve energy efficiency of IORM extraction, it is necessary to emphasize that intrinsically they are the three basic strategic actual ones:

- the substantiated scheduling and optimization of level of EE supply-consumption by an enterprise depending upon its output;

- the decreased EE losses in the process of its delivery and consumption in the context of electric power complex of an enterprise;

- the redistribution of the electric power flows depending upon a day part according to the available hourly rates for the consumed EE.

Analysis of the listed should involve such an idea that implementation of tendency one is quite limited as for its visualization [3], [9]. However, there is no necessity to reject it as one of real tendencies. Instead, it has to be applied at least to normalize the planned specific EE consumption per ton of IORM being extracted. Tendency two has real and fundamental prospect expecting its implementation through time. Meanwhile, leaving search for implementation of the tendency as well as previously concerned one for future research and taking into consideration the limited specifity of the paper volume turn our attention to tendency three. Moreover, in the context of the current situation just the priceoriented approach is one of the scientific and research tendencies connected with optimum control of energy flows within the system of electrical energy systems of enterprises in terms of a day part. The approach involves both economic and engineering aspects of the process. As it is understood from practices of economically developed countries, such an approach is virtually implementable with minimum investment for its implementation [6], [8]. However, application of foreign research under the conditions of the national iron-ore enterprises is quite problematic idea. First of all, it concerns differences in IORM extraction methods as well as types of facilities involved.

Generally, the studies carried out during the last decades regarding the abovementioned purpose achievement tended towards the idea to consider the problem locally without sufficient formatting of tactics to solve the problem wholistically. Analysis of results of the available research in terms of the considered aspect [9][12] supports insufficiency of the required integral concept to develop systems controlling electric power flows of underground iron-ore enterprises. In turn, that prevents from provision of adequate control level by means of correlation and complexity of the tasks being implemented by the system.

The integrated automation of control of resource consumption and operating procedures (OP) of mines remains one of the most promising measures to improve the situation on the basis of intelligent, optimal, and adaptive controlling.

Currently, strategies to develop the automated control systems (ACS) demonstrate their rather active progress. They 
are based upon the use of artificial-intelligence technologies (for instance, neural networks, fuzzy logic, genetic algorithms, synergetics etc.). Precisely such control systems makes it possible to solve the problems owing to use of mathematical models of human intelligence (i.e. educability; capacity for self-organization and generalization; experience accumulation etc), built-in nonlinearity, and adaptivity. Thus, taking into consideration the available uncertainty, the improvement of approaches of intelligent control of energy consumption as well as material flows (i.e. ore, water, and air) of mines relying upon fuzzy logic is quite expedient and promising research tendency.

Hence, the last-mentioned approach has been selected by the authors to implement ACS of energy consumption in a mine. Passive experiment and computer modeling on the basis of the current IT are proposed as underlying tools for the approbation.

The research objective is to substantiate tactics and develop theoretical aspects for designing and functioning of ACS of energy flows of underground iron-ore enterprises.

Scientific problems to be solved by the paper are the following:

- analysis of EE flow distribution and formatting of energy intensive EE consumers of iron-ore mines;

- development of algorithm for ACS of electric energy flows;

- simulation and development of a fuzzy regulator to control electric energy flows of iron-ore mines.

\section{Results and discussion}

In the context of iron-ore enterprises, engaged in underground IORM mining and processing, the problem of electric energy efficiency is not limited by one fact of significant total electric capacity of EE consumers. It is complicated by sizeable fluctuations of the consumed power and EE levels in terms of days, months, and seasons. Day fluctuations of EE consumption are characterized by the greatest range [2]. The fact can be explained by the available method of underground mining [2]. Such fluctuation levels are not typical even for coal mines, shale mines, salt mines and other types of mine being the closest to iron-ore mines (pits).

As [3] has determined, in the context of EE consumption by iron-ore mines, the range of available hourly fluctuations exceeds quadruple values. Furthermore, cost for the consumed EE for underground iron-ore enterprises depends upon its consumption level during the certain day part.

The Law of Ukraine [5] changed available calculation pattern between enterprises, consuming $\mathrm{EE}$, and powergenerating companies. In the context of underground mining enterprises, it is a transition to an hourly payment option. Inherently, they shift from three-rate pricing schedule (i.e., "peak" - "semipeak" - "night") to a two-rate one (i.e. "peak" - "not peak"). Such a calculation "restructuring" resulted in almost instant response. Enterprises started to pay more for the consumed EE. From 2019, when the Law of Ukraine was implemented, EE percentage in the prime cost of IORM extraction increased by more than $6 \%$ to compare with 2017.

Under the conditions of the available economic situation, national mining enterprises, engaged in underground IORM extraction try to redistribute levels of energy flows. Under the current economic situation, the national enterprises, en- gaged in underground IORM extraction, like no other mining ones try to redistribute levels of electric energy flows while using tariff difference for the consumed EE depending upon a day part. They do it to maximize the consumed EE amount shift to economic tariff zones. For the purpose, underground iron-ore enterprises schedule operationally relevant amount of EE consumption. However, such a variant of a "hand regulation" is not efficient enough. As a rule, in terms of such regulation "plan" differ greatly from "actuality" (Fig. 2). The latter influences negatively a process of formation of the prime cost of IORM extraction.

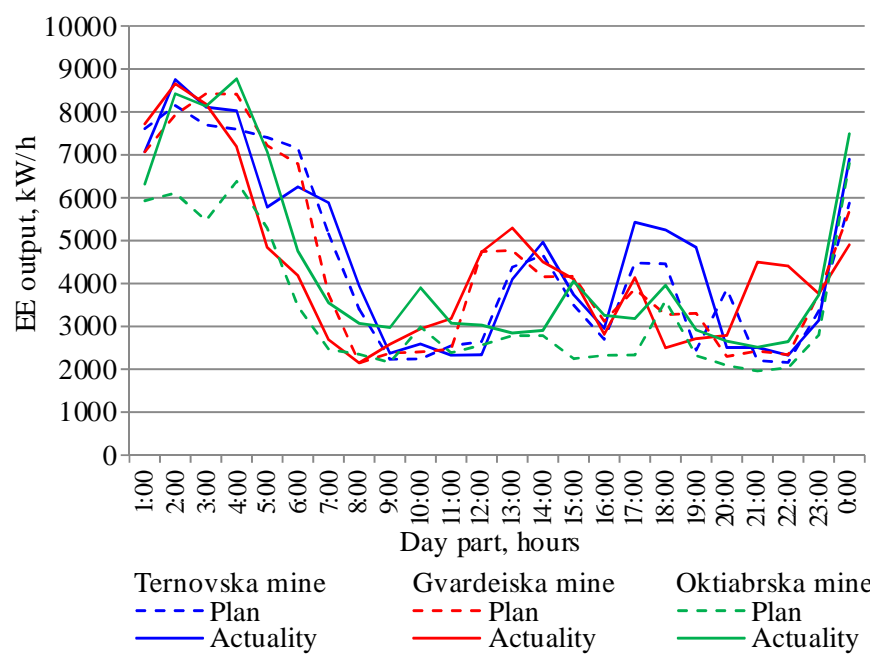

Figure 2. Ratio between the planned and actual levels of electric energy consumption in terms of certain mines of Kryvyi Rih iron-ore basin (November 12, 2019)

If one relies upon the preventive logic, it becomes understood that strategic tendency of the studied problem to improve power efficiency of IORM underground extraction is ACS implementation in the practices of mining enterprises for power flows, and ACS subsystem for electric energy flows.

It makes sense that ACS efficiency for power flows will depends upon one or another control algorithm to be implemented. The algorithm is based upon the control function of rather actual parameters and influential factors. Evaluation level of the realias should involve and apply relevant practices of mining enterprises. Currently, the majority of mining and smelting enterprises use more or less efficiently automatic systems for commercial accounting of power consumption (ASCAPC). The systems help operators collect, accumulate, process, store, and display certain amount of information; form electricity consumption balances; and perform both commercial and technical accounting of the consumed EE levels.

Meanwhile, EE consumption control as well as statement of the current loads is not sufficient thing today in the context of functional capabilities of the current computer equipment and, above all, economic situation of mining enterprises. The modern techno-economic conditions of enterprise activities impose the necessity to control the processes. The ultimate objective of the approach is ACS for energy flows. Moreover, the ACS should have elements of intelligent control of the process. Unfortunately, implementation level of such ACSs as for the activities of mining and smelting enterprises leaves much to be desired.

We believe that following problems are the key one as for the tendency: 
- lack of the unified balanced methodological approach to the development of efficient systems to control EE consumption levels - ACS for energy flows with ACS subsystem for electric power flows;

- necessity of substantial one-time investment which cannot be placed by iron-ore enterprises and ore mines especially. The matter is that a scheme to settle payment relations between enterprises, consuming $\mathrm{EE}$, and generating companies is based upon the restricted hour tariffs. In terms of the latter, payment levels differ greatly.

As a control object under the conditions of underground iron-ore enterprises, the considered tariff plan is a multiparameter, nonlinear, and multiconnected one [13]-[15]. First, it is required to identify controlling phase space using a system analysis [16][18].

As it has been determined by [19][20], the key EE consumers in iron-ore mines are: technological conversions of IORM extraction/transportation; mine drainage; air delivery; and ventilation. Taking into consideration the abovementioned, it is necessary to identify potential control parameters as the expression of the type (1)-(5):

$$
\begin{aligned}
& Z^{e}=F(R E, H T) \Rightarrow \min \\
& P \Rightarrow \max \\
& B \Rightarrow \max \\
& B_{d} \Rightarrow \max \\
& B_{m} \Rightarrow \max
\end{aligned}
$$

where:

$Z^{e}$ - total enterprise expenditures connected with the consumed electric energy (hourly, daily), UAH;

$R E$ - power consumption (hourly, daily), $\mathrm{kW}$;

$H T$-current electricity tariff, UAH/kW;

$F(\ldots)$ - certain determined functional dependence;

$P$ - ore mass extraction by an enterprise (hourly, daily), t;

$B-$ air delivery (hourly, daily), $\mathrm{m}^{3}$;

$B_{d}$ - volume of mine water pumpage (hourly, daily), $\mathrm{m}^{3}$;

$B_{m}-$ ventilation (hourly, daily), $\mathrm{m}^{3}$.

Considering the potential complexity of such multicriteria problem solving, it is proposed to replace ultimately some of the abovementioned minimax criteria by limitations of the type:

$$
\begin{aligned}
& P \geq P^{\mathrm{min}} ; \\
& B \geq B^{\mathrm{min}} ; \\
& B_{d} \geq B_{d}^{\min } ; \\
& B_{m} \geq B_{m}^{\min },
\end{aligned}
$$

where:

$P^{\mathrm{min}}, B^{\mathrm{min}}, B_{d}^{\mathrm{min}}, B_{m}{ }^{\mathrm{min}}$ - certain boundary values of corresponding parameters (for instance, daily planned values).

Thus, values of EE consumption levels in terms of the system or in terms of certain redistributions from a local criterion of an objective function (1) may be redefined as follows:

$$
R E=f\left(P, B, B_{d}, B_{m}\right),
$$

where: $f(\ldots)$ - certain function or approximation.

As it has been demonstrated by [21], the listed factors are rather informative ones for the current conditions of the system (a mine). At the same time, in terms of the specific mine, the parameters of ore flow, pumping, ventilation, and air delivery may influence differently the resulting factor, i.e. power consumption. Hence, the indices should be involved in a state vector of our system $X=\{\ldots\}$. At the same time, depending upon a correlation degree between them, certain parameters may be considered as control disturbance ( $U=\{\ldots\}$ is corresponding vector) or as a disturbing factor $(V=\{\ldots\}$ vector). As a result, the generalized structural scheme of automated control of power consumption by a standard iron-ore may look like in Figure 3.

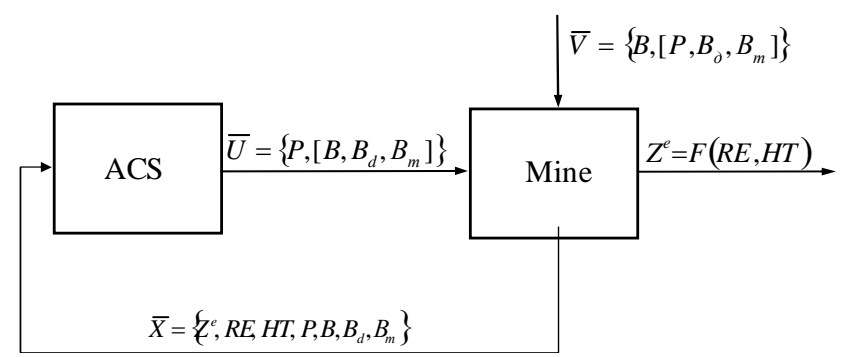

Figure 3. Generalized structural scheme of automated power consumption control in terms of underground iron ore mining: $\bar{X}=\left\{Z^{e}, R E, H T, P, B, B_{\partial}, B_{m}\right\}$-vector of the system state with corresponding elements; $\bar{U}=\left\{P,\left[P, B_{\partial}, B_{m}\right]\right\}$ - vector of control disturbance); and $\bar{V}=\left\{B,\left[P, B_{\partial}, B_{m}\right]\right\}$-vector of disturbance influence

According to the common classification [21], the control scheme is of a closed type with a feedback coupling. Power consumption process with the required frequency (day, month, year etc.) is the control object). ACS, which functional structure and operation algorithms will be developed and proposed later, is the control subject. Composition of elements of control vectors $\bar{U}$ disturbance influence $\bar{V}$ may vary depending upon a specific mine. The final decision should be made relying upon correlation analysis [20], [22] which will be taken into consideration in the process of the control algorithm development. In turn, $Z^{e}, R E, H T$ parameters are integral information components of a state vector of $\bar{X}$ system. The same is true for the selection of control criteria in a minimax form of (1)(5) type or a marginal approach on the basis of the key criterion selection (1) involving limitations of (6-9) type.

\subsection{Algorithm developing on the basis of fuzzy logic}

In the context of nonlinear characteristics, often incomplete information, and channelling, use of up-to-date intelligent approaches to implement the automated control, based upon fuzzy logic, is rather promising strategy [23].

On the basis of the approach, the authors have developed and implemented programmatically an operation approach of a fuzzy control system (Figs. 4 and 5). The approach involves several control strategies, namely:

$$
S=\left\{\begin{array}{l}
P, P+B_{m}, P+B_{d}, B_{m}, 0, B_{d}+ \\
+B_{m}, B_{d}, P+B_{m}+B_{d}
\end{array}\right\} .
$$




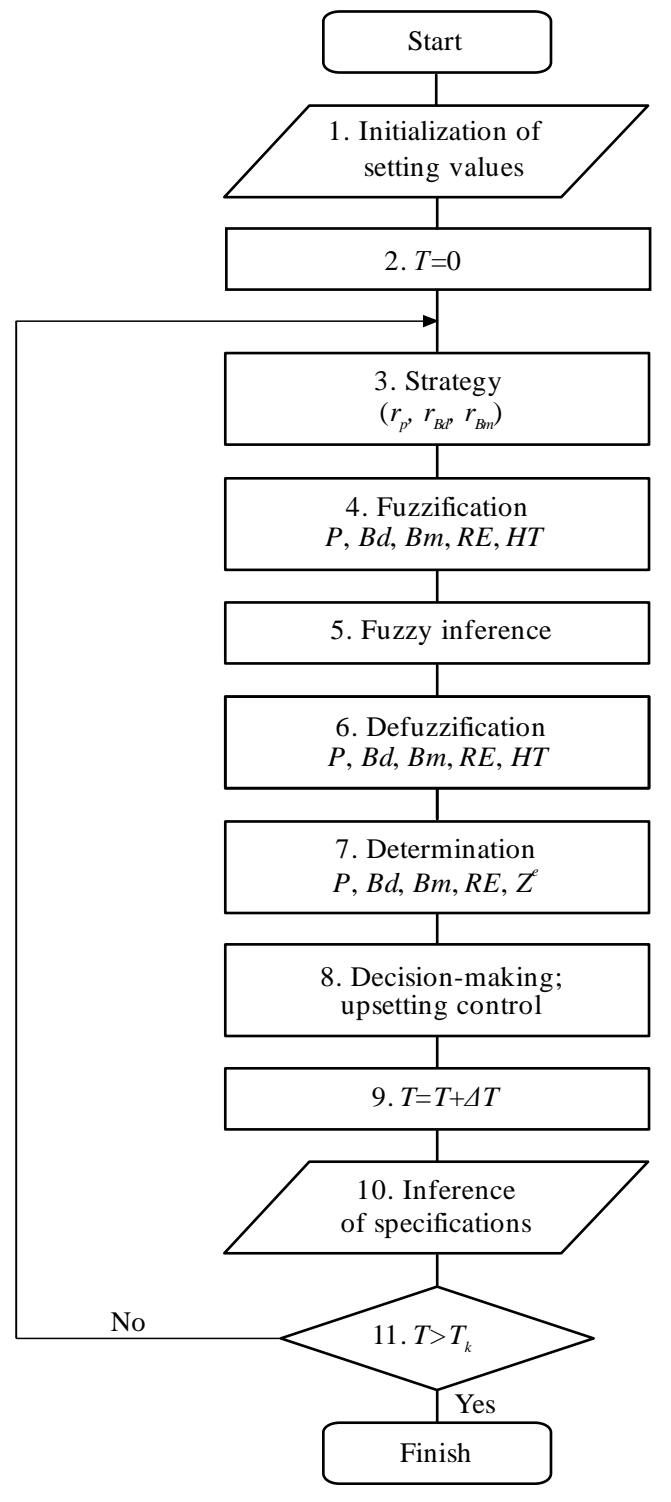

Figure 4. Operation algorithm of a fuzzy ACS
Each strategy defines the number of possible control influences (i.e. control channels) to be implemented for ACS in future. For instance, according to the presented set (11), the number of such parameters may be 0 (if there is no control or "manual mode" is applied), 1, 2 or 3. However, it should be noted that in terms of the method, the number of channels may be increased in the future if required.

It should also be mentioned that according to (1) and (10), potential electric energy expenditures $Z^{e}$ are the key controlled factor. In turn, the expenditures depend upon electric energy consumption $R E$ and hourly rate $H T$.

The algorithms involve cascade of hush conditional operator with control of values of correlation coefficients between $\left[P, B_{d}\right.$, and $\left.B_{m}\right]$, and $[R E]$ (in pairs) with aggregation by means of connective words of AND/OR type. Excess of a threshold value (i.e., $\left.\left|r_{x y}>0.7\right|\right)$ will mean the necessity to consider the control channel (or control influence) in the resulting strategy.

Hence, the developed algorithm determines the specific control strategy corresponding to the number of control channels: 1, 2 or 3. For instance, in terms of ore; in terms of ore and water; in terms of ore, water, and ventilation.

\subsection{Principles of fuzzification and formation of a base of logical inference rules in the context of one-channel control}

The control type is implemented by means of one of possible influences from (11). According to the algorithm (Fig. 5) they may be strategies 1, 4 or 7 . Consider principles of fuzzification and formation of a base of logical inference rules for one-channel control in terms of strategy 1 . In this context, ore flow $P$ is control influence; a value of electric energy consumption from (10) will be the controlled parameter. Parameters of pumping, air delivery, and ventilation are referred to disturbance ones.

Relying upon the methods, described in [24], [25], determine a base fuzzy set to be formalized for our system. In our case, the set will consist of the three elements $(N=3)$.

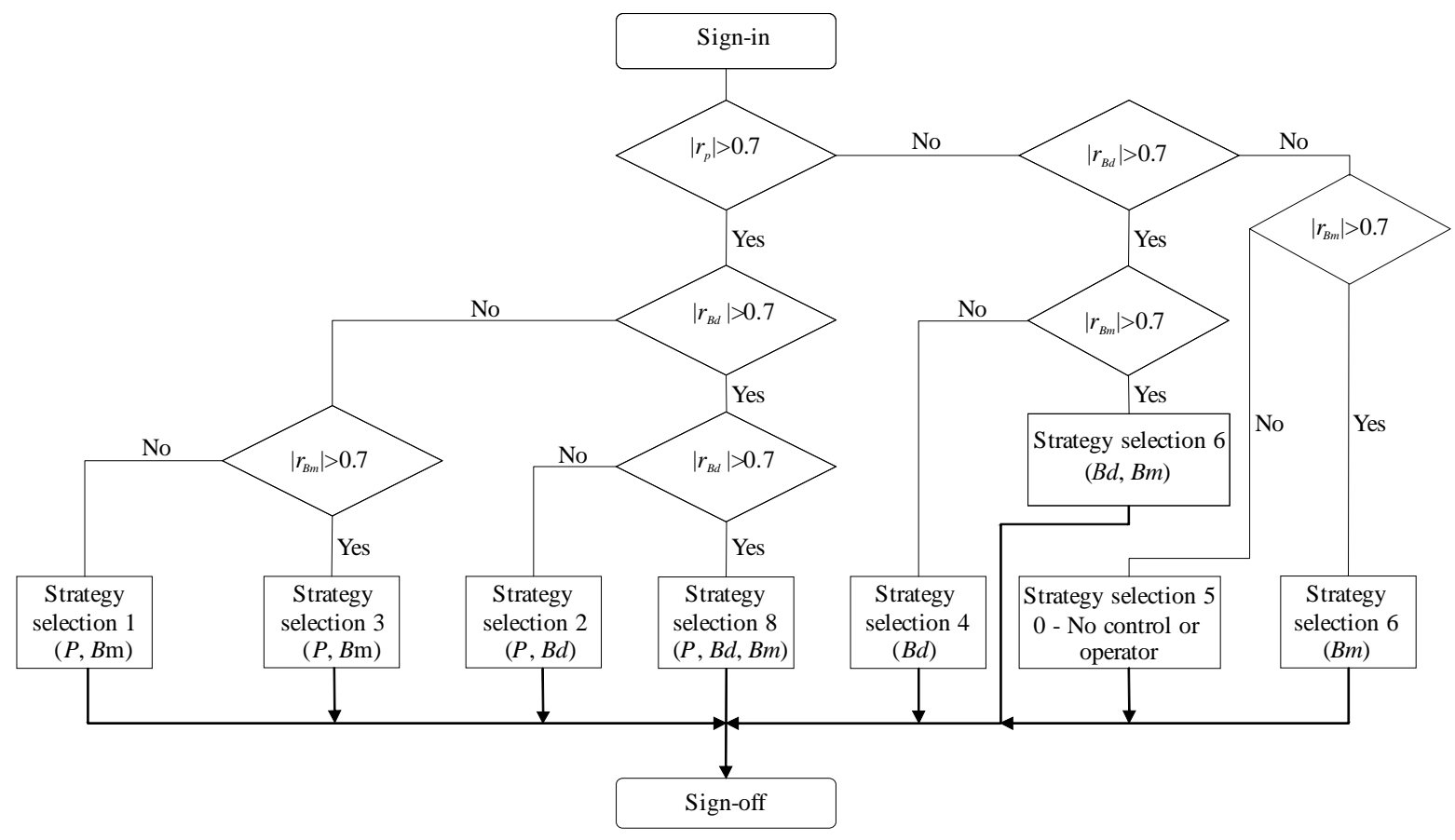

Figure 5. Algorithm of a procedure to select the control strategy 


$$
\begin{aligned}
& \bar{B}=\bigcup_{i=1}^{N}\left\{\frac{\beta_{i}}{\mu\left(\beta_{i}\right)}\right\}=\left\{\frac{\beta_{1}}{\mu\left(\beta_{1}\right)} ; \frac{\beta_{2}}{\mu\left(\beta_{2}\right)} ; \frac{\beta_{3}}{\mu\left(\beta_{3}\right)}\right\}= \\
& =\left\{\frac{\beta_{R E}}{\mu\left(\beta_{R E}\right)} ; \frac{\beta_{H T}}{\mu\left(\beta_{H T}\right)} ; \frac{\beta_{P}}{\mu\left(\beta_{P}\right)}\right\}
\end{aligned}
$$

where:

$$
\bar{B} \text { - base fuzzy set; }
$$

$\beta_{i}$-fuzzy value of the determined parameter (for instance, control parameter or controlled one);

$\beta_{1}=\beta_{R E}-$ corresponding fuzzy value for power consumption parameter;

$\beta_{2}=\beta_{H T}-$ fuzzy value for the tariff;

$\beta_{3}=\beta_{P}-$ fuzzy value of ore flow;

$\mu\left(\beta_{i}\right), \mu\left(\beta_{1}\right), \mu\left(\beta_{2}\right), \mu\left(\beta_{3}\right), \mu\left(\beta_{R E}\right), \mu\left(\beta_{H T}\right), \mu\left(\beta_{P}\right)$-value of membership function for corresponding parameters.

Determine sets of linguistic variables (i.e. terms) for all the abovementioned fuzzy parameters:

$$
T_{1}^{E E}=\left\{\begin{array}{l}
\frac{M I N}{N B} ; \frac{\text { less_than_average }}{N S} ; \\
\frac{\text { average }}{Z} ; \frac{\text { more_than_average }}{P S} ; \frac{M A X}{P B}
\end{array}\right\} ;
$$

$T_{2}^{\text {Tariff }}=\left\{\frac{\text { night }}{N S} ; \frac{\text { semipeak }}{Z} ; \frac{\text { peak }}{P S}\right\} ;$

$$
T_{3}^{\text {Ore }}=\left\{\begin{array}{l}
\frac{M I N}{N B} ; \frac{\text { less_than_average }}{N S} ; \\
\frac{\text { average }}{Z} ; \frac{\text { more_than_average }}{P S} ; \frac{M A X}{P B}
\end{array}\right\} ;
$$

where:

$T_{1}^{E E}, T_{2}^{\text {Tariff }}, T_{3}^{\text {Ore }}$-identifiers of multivariate terms for fuzzy variables: EE consumption, tariff making, and ore flow;

$\{M I N$, less_than_average, average, more than average, $M A X\}+\{$ night, semipeak, peak $\}, \quad\{N B, \quad N S, \quad Z, \quad P S$, $P B\}+\{N S, Z, P S\}-$ integrated or abbreviated identifiers to specify corresponding values of the terms.

As it is understood from (13)-(15) sets, following operation should involve five-unit scale assumed as power consumption and ore flow parameters; and three-unit scale is assumed for the tariff variable.

Following operational stage is to define the database with rules for logical inference. Taking into consideration the fact that it is planned to use later Mamdani algorithm to the fuzzification [22], previously determined fuzzy sets (12), and corresponding terms (13)-(15), rules of fuzzy inference will be formed as follows:

$1)$ if "Electric Energy Consumption" $\left(\beta_{1}\right)=$ "MIN" $(N B)$ and "Tariff" $\left(\beta_{2}\right)=$ "Peak" (PS) then "Ore Flow" = "MIN" $(N B)$;

$2)$ if "Electric Energy Consumption" $\left(\beta_{1}\right)=$ "Average" $(Z)$ and "Tariff" $\left(\beta_{2}\right)=$ "Semipeak" $(Z)$ then "Ore Flow" = "Average" (Z);

$3)$ if "Electric Energy Consumption" $\left(\beta_{1}\right)=$ "MAX" $(P B)$ and "Tariff" $\left(\beta_{2}\right)=$ "MIN" $(N S)$ then "Ore Flow" = "MAX" (PB).

Standard Mamdani methods will be used as a base algorithm for following defuzzification procedure.

\subsection{Principles of fuzzification and formation a base of logical inference rules in the context of a multichannel control}

The control type is implemented by means of one of possible influences from (11). According to the algorithm (Fig. 5) it may be strategy 8 . Ore flow $P$, pumpage $B_{d}$ and ventilation $B_{m}$ are controlling influence; and a value of electric energy consumption from (10) will be the controlled parameter. General principles of fuzzification and formation a base of logical inference rules for three-channel control are the following.

Base fuzzy set (16) is applied to implement three-channel control. In our case, the set will consist of 5 elements $(N=5)$ :

$$
\begin{aligned}
& \bar{B}=\bigcup_{i=1}^{N}\left\{\frac{\beta_{i}}{\mu\left(\beta_{i}\right)}\right\}=\left\{\begin{array}{l}
\frac{\beta_{1}}{\mu\left(\beta_{1}\right)} ; \frac{\beta_{2}}{\mu\left(\beta_{2}\right)} ; \frac{\beta_{3}}{\mu\left(\beta_{3}\right)} ; \\
\frac{\beta_{4}}{\mu\left(\beta_{4}\right)} ; \frac{\beta_{5}}{\mu\left(\beta_{5}\right)}
\end{array}\right\}= \\
& =\left\{\begin{array}{l}
\frac{\beta_{R E}}{\mu\left(\beta_{R E}\right)} ; \frac{\beta_{H T}}{\mu\left(\beta_{H T}\right)} ; \frac{\beta_{P}}{\mu\left(\beta_{P}\right)} ; \\
\frac{\beta_{B_{d}}}{\mu\left(\beta_{B_{d}}\right)} ; \frac{\beta_{B_{m}}}{\mu\left(\beta_{B_{m}}\right)}
\end{array}\right\}
\end{aligned}
$$

where:

$\beta_{5}=\beta_{B m}-$ fuzzy set for pumping;

$\mu\left(\beta_{5}\right), \mu\left(\beta_{B m}\right)$-corresponding value of a membership function.

Then, the sets of terms, determined above, should be added by a term determination.

Determine sets of linguistic variables (i.e. terms) for all the mentioned fuzzy parameters:

$T_{5}^{\text {Vent }}=\left\{\begin{array}{l}\frac{M I N}{N B} ; \frac{\text { less_than_average }}{N S} ; \\ \frac{\text { average }}{Z} ; \frac{\text { more_than_average }}{P S} ; \frac{M A X}{P B}\end{array}\right\}$,

where:

$T_{5}{ }^{\text {Vent }}$ - identifier of a term for a fuzzy variable of air ventilation amount in a mine.

Taking into consideration (16)-(17), exemplify several cases to formulate fuzzy inference rules for such control type:

$1)$ if "Electric Energy Consumption" $\left(\beta_{1}\right)=$ "MIN" $(N B)$ and "Tariff" $\left(\beta_{2}\right)=$ "Peak" $(P S)$ then "Ore Flow" = "MIN" $(N B)$, "Water Pumping" = "MIN" $(N B)$, "Ventilation" = "MIN" (NB);

$2)$ if "Electric Energy Consumption" $\left(\beta_{1}\right)=$ "Average" $(Z)$ and "Tariff" $\left(\beta_{2}\right)=$ "SemiPeak" $(Z)$ then "Ore Flow" = "Average" $(Z)$, "Water Pumping" = "Average" $(Z)$, "Ventilation" = "Average" (Z);

$3)$ if "Electric Energy Consumption" $\left(\beta_{1}\right)=$ "MAX" $(P B)$ and "Tariff" $\left(\beta_{2}\right)=$ "MIN" $(N S)$ then "Ore Flow" = "MAX" $(P B)$, "Water Pumping" = "MAX" $(P B)$, "Ventilation" = "MAX” $(P B)$.

\subsection{Methods to identify optimum settings}

It is necessary to synthesize optimum settings if marginal criterion of type (1) is used in terms of limitations of the basic controlling influence and/or disturbance of (6)-(9) type taking into consideration (10) and three-zone electricity tar- 
iff. Logic of obtaining of such settings relies upon application of a minimax approach to control power and material flows in a mine, namely:

- in terms of maximum (i.e. peak) tariff value $\beta_{2}=P S$, it is advisable to consume electric power minimally at the expense of minimization of material flows (i.e. ore, water, air etc.);

- in terms of minimum (i.e. night) tariff value $\beta_{2}=N S$, maximum power consumption may be accepted at the expense of maximum material flows;

- alternatively, in terms of a possible intermediate tariff value $\beta_{2}=Z$, balancing electric power consumption is applied at the expense of corresponding amounts of material flows.

Taking advantage of the logic, formalize such settings in terms of each possible optimization channel. Thus, we have for an ore flow:

$$
P_{i}^{*}=1 \ldots T^{\Delta}=\left\{\begin{array}{l}
\max \left[P_{i}^{\text {day }}\right], \quad \text { if }\left(\beta_{2}=N S\right) \\
\min \left[P_{i}^{\text {day }}\right], \quad \text { if }\left(\beta_{2}=P S\right) \\
K^{*}\left(\max \left[P_{i}^{\text {day }}\right]+\min \left[P_{i}^{\text {day }}\right]\right) / 2, \\
\text { if }\left(\beta_{2}=Z\right),
\end{array}\right.
$$

where:

$P_{i}{ }^{*}$ - setting value (definition) of ore extraction in terms of $i^{\text {th }}$ step $\left(i=1 \ldots T^{\Delta}\right)$;

$T^{4}$ - the number of discrete intervals for the parameter (ore) measurement per day (for instance, if discrete periodicity of a parameter measurement is assumed as $\Delta t=30 \mathrm{~min}=0.5 \mathrm{~h}$, then $T^{4}=48$ measurements in terms of ore per day);

$\max \left[P_{i}^{d a y}\right], \min \left[P_{i}^{d a y}\right]-$ maximum/minimum of all possible discrete values of IORM extraction per day (of all the measurement sample);

$K^{*}$ - certain adjusting factor.

Actual value of the latter is determined using a balancing daily coefficient taking into consideration the fact that daily ore output should be at a level of certain plan value $P_{p l}$ day . Then,

$$
\begin{aligned}
& T^{\max } \cdot \max \left[P_{i}^{\text {day }}\right]+T^{\min } \cdot \min \left[P_{i}^{\text {day }}\right]+ \\
& +\tilde{T} \cdot K^{*}\left(\max \left[P_{i}^{\text {day }}\right]+\min \left[P_{i}^{\text {day }}\right]\right) / 2=P_{p l}^{\text {day }}
\end{aligned}
$$

where:

$T^{\mathrm{max}}$ - number of maximum discrete periods with corresponding ore extraction (i.e. in terms of a "Night" tariff);

$T^{\mathrm{min}}$ - number of minimum (i.e. in terms of a "Peak" tariff);

$\tilde{T}$ - number of discrete balancing periods with intermediate (adjusting) extraction level (i.e., in terms of a "Semipeak" tariff);

$T^{\max }+T^{\min }+\tilde{T}=T^{\Delta} ; i=1 \ldots T^{4}$.

Then in terms of $T^{4}=48$ of discrete measurements of technological parameters $\Delta t=30 \mathrm{~min}(0.5 \mathrm{~h})$, obtain the following for a scale of the current three-rate electricity tariff for industrial enterprises: $T^{\max }=13 ; T^{\min }=14 ; \tilde{T}=21$. Inserting the data into (21), obtain:

$$
\begin{aligned}
& 13 \cdot \max \left[P_{i}^{\text {day }}\right]+14 \cdot \min \left[P_{i}^{\text {day }}\right]+ \\
& +21 \cdot K^{*}\left(\max \left[P_{i}^{\text {day }}\right]+\min \left[P_{i}^{\text {day }}\right]\right) / 2=P_{p l}^{\text {day }},
\end{aligned}
$$

$$
K^{*}=\frac{P_{p l}^{d a y}-\left(13 \cdot \max \left[P_{i}^{d a y}\right]+14 \cdot \min \left[P_{i}^{\text {day }}\right]\right)}{10.5\left(\max \left[P_{i}^{d a y}\right]+\min \left[P_{i}^{\text {day }}\right]\right)} .
$$

Use of identical transformation has helped derive similar settings of (20) and (23) type for other optimization channels (i.e. water, air etc).

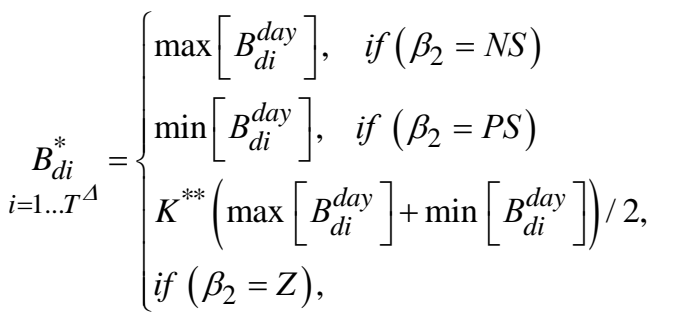

where:

$B_{d i}{ }^{*}$ - value of definition (setting) as for the amount of a mine water pumping in terms of $i^{\text {th }}$ optimization step $\left(i=1 \ldots T^{\Delta}\right)$;

$\max \left[B_{d i}^{d a y}\right], \quad \min \left[B_{d i}^{d a y}\right]-$ maximum/minimum of all possible discrete values of daily mine water amount pumping (c of all the measurement sample) respectively);

$K^{* *}$ - certain adjusting factor.

In this context:

$$
K^{* *}=\frac{B_{p l}^{d a y}-\left(13 \cdot \max \left[B_{d i}^{d a y}\right]+14 \cdot \min \left[B_{d i}^{d a y}\right]\right)}{10.5\left(\max \left[B_{d i}^{d a y}\right]+\min \left[B_{d i}^{d a y}\right]\right)},
$$

where:

$B_{p l}{ }^{d a y}$ - plan of a daily amount of mine water pumping.

Similarly to ventilation index:

$$
\underset{i=1 \ldots T^{\Delta}}{B_{m i}^{*}}=\left\{\begin{array}{l}
\max \left[B_{m i}^{\text {day }}\right], \quad \text { if }\left(\beta_{2}=N S\right) \\
\min \left[B_{m i}^{\text {day }}\right], \quad \text { if }\left(\beta_{2}=P S\right) \\
K^{* * * *}\left(\max \left[B_{m i}^{\text {day }}\right]+\min \left[B_{m i}^{\text {day }}\right]\right) / 2, \\
\text { if }\left(\beta_{2}=Z\right),
\end{array},\right.
$$

where:

$B_{m i}{ }^{*}$ - setting in terms of air ventilation amount in a mine in terms of $i^{\text {th }}$ optimization step $\left(i=1 \ldots T^{\Delta}\right)$.

$\max \left[B_{m i}^{d a y}\right], \quad \min \left[B_{m i}^{d a y}\right]-$ maximum/minimum of all possible discrete values of daily mine ventilation index (of all the measurement sample);

$K^{* * *}$ - certain adjusting factor.

In this context:

$$
K^{* * * *}=\frac{\tilde{B}_{p l}^{d a y}-\left(13 \cdot \max \left[B_{m i}^{d a y}\right]+14 \cdot \min \left[B_{m i}^{d a y}\right]\right)}{10.5\left(\max \left[B_{m i}^{d a y}\right]+\min \left[B_{m i}^{d a y}\right]\right)},
$$

where:

$$
\tilde{B}_{p l}^{d a y}-\text { plan of daily mine ventilation. }
$$

\subsection{Computer modeling of fuzzy ACS operation}

To simulate operation of ACS for electric power consumption, use the environment of Fuzzy Logic Toolbox (FLT) modulus from the software mathematical application package MATLAB. For the purpose, apply a standard method of fuzzy modeling described in papers [25]-[27]. 
Develop a fuzzy controller in terms of a one-channel control "Ore Flow-Electric Energy Consumption" basing upon data statistics generated in Rodina mine (town of Kryvyi Rih, Ukraine). Taking into consideration the defined above fuzzy variables, fuzzy sets (12)-(15), and membership function, input parameters as well as output parameters are set in editing program FIS. It is also understood that Mamdani algorithm will be used for further defuzzification [23].

3-D model of a surface for fuzzy inference for the developed fuzzy model has been obtained relying upon the data (Fig. 6).

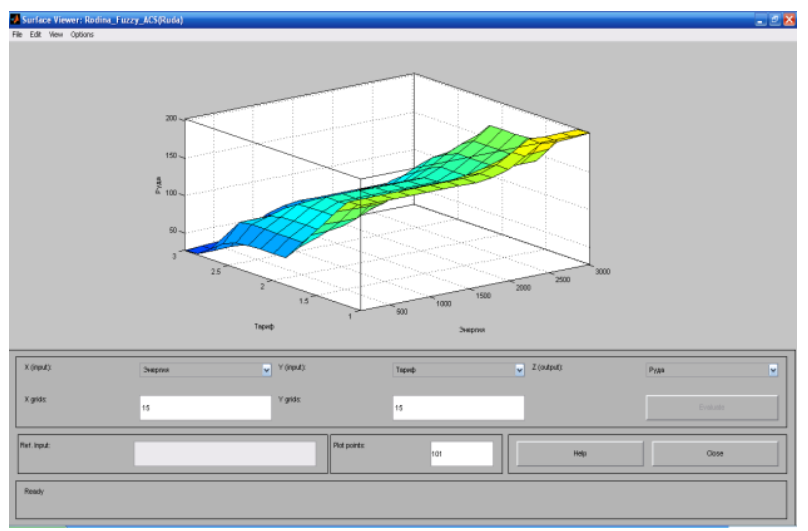

Figure 6. 3-D model of a surface for fuzzy inference of a fuzzy model (according to Rodina mine data)

Figures 7 and 8 demonstrate operational results of a fuzzy one-channel ACS for electric energy consumption based upon one controlling influence - daily time-spaced ore output. Discreteness of the controller modeling was $0.5 \mathrm{~h}-30 \mathrm{~min}$.

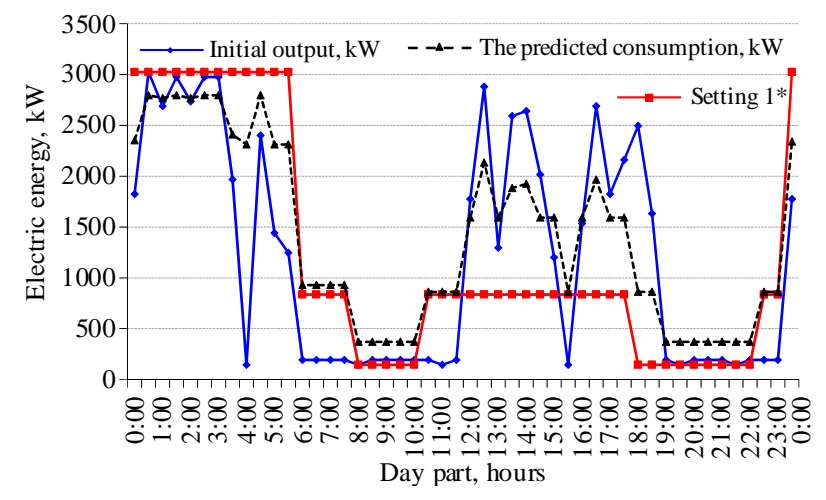

Figure 7. Dependences of the consumed active EE capacity (1); development of optimum setting $1 *$ of (20) type; and the predicted EE consumption in terms of minimax control

Analysis of the modeling results, shown in Figures 5 and 6 , and analytical calculations illustrate the following. Use of minimax criteria of (1) and (2) types in terms of Rodina mine makes it possible to increase daily ore output by $14.85 \%$ (i.e. by more than 600 tons per day). In this context, daily electric energy consumption will increase similarly by $14.86 \%$ (being almost 0.9 taking into consideration high correlation coefficient [4]). Expenditures, connected with electric energy consumption will increase by $10.83 \%$ inclusive of three-zone tariff. However, in terms of the current payable iron ore cost in the world market, it may be compensated by potential profits resulting from extra IORM amount sales.

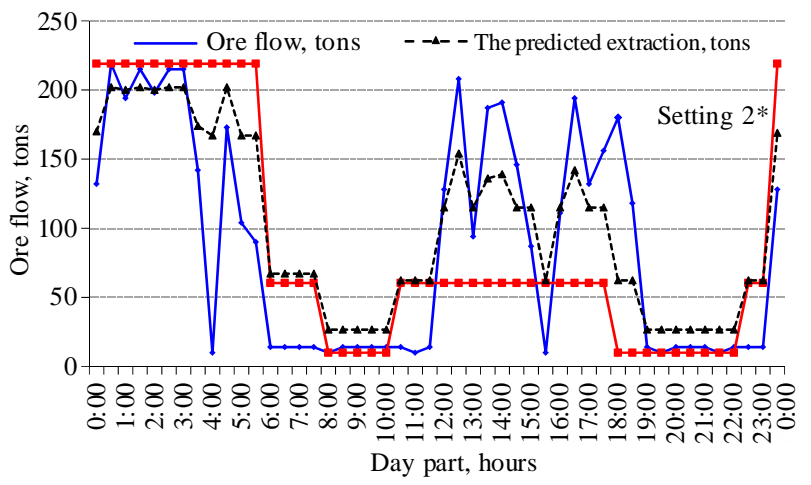

Figure 8. Dependences in terms of ore flow (2) in a mine as a control channel; development of optimum setting $2 *$ of (20) type; and mining output in terms of maximization of the latter (i.e. minimax control) according to a criterion of (2) type

Use of the optimum settings, derived on the basis of expressions of (21) type, and (1) and (6)-(9) criteria, helps maintain the planned value of daily IORM output. In this context, more rational time-spaced (i.e. zonal tariff) electricity consumption redistribution may help reduce daily expenditures by $27.51 \%$. The basic principles of development of fuzzy controllers as well as their operational algorithms in the context of multichannel control were described above.

Taking into consideration the fact that control implementation in terms of two control channels (i.e. "Ore-Water") is identical to the abovementioned ones, confine ourselves to the description of computer modeling results on channel three ("Water", Fig. 9), and the total electric energy consumption (Fig. 10) according to the three process stages (i.e. Extraction, Pumpage, and Ventilation).

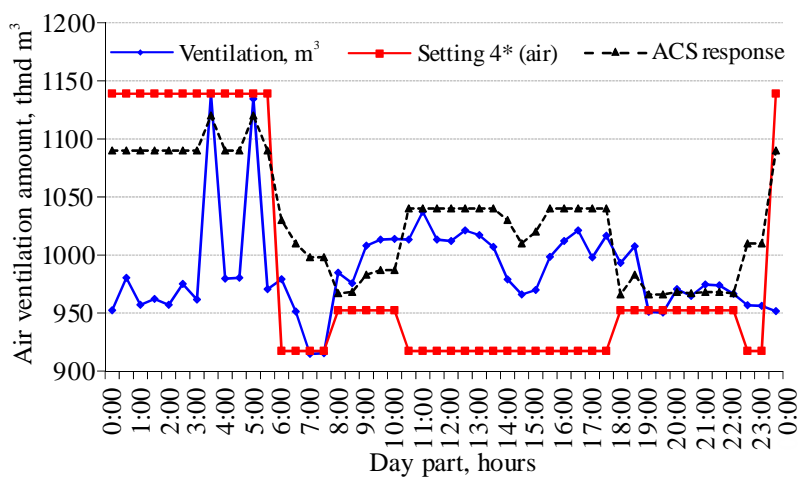

Figure9. Modeling of minimax regulation and optimum control on the "Air" channel ("Air ventilation")

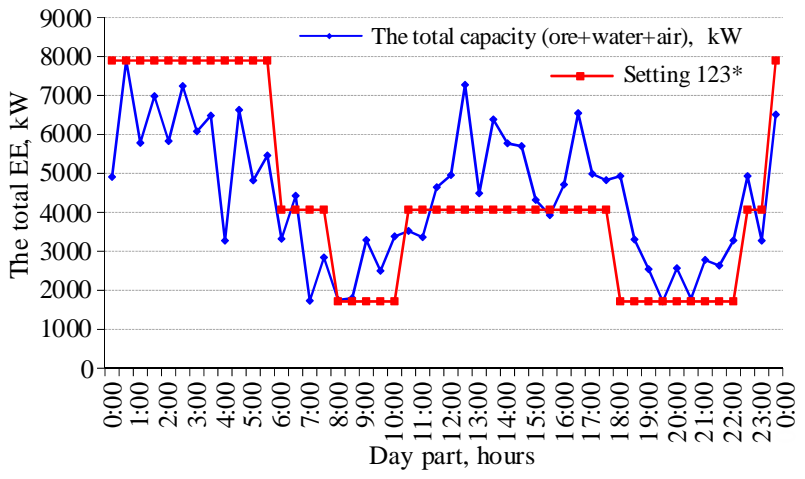

Figure 10. Results of three-channel (i.e. "Ore-Water-Air") control of the total EE consumption based upon optimum setting ("Setting 123*") 
Use of control based upon optimum setting $123^{*}$ of (24) and (26) type will result in the achievement of the planned daily IORM output. However, aggregate expenditures, connected with daily EE consumption, will be decreased expectedly by $16.23 \%$. That will depends upon more rational distribution of ore and water flows as well as corresponding power consumption in terms of process stages under the conditions of three-zone tariff.

\subsection{Discussion of the research results concerning a problem of automation of the mine electric power consumption control}

The obtained results can be explained by rather high efficiency of the automated control of electric power flows in a mine based upon fuzzy logic method. Use of several control strategies is the feature of the techniques to develop fuzzy controllers. All the proposed strategies demonstrated positive results in the context of the modeling. Application of the fixed set of linguistic terms at the rate of 3-5 elements as well as rather limited set of statistical data sampling in the verification process are the key restrictions of the research. To improve adequacy of the modeling results, it is necessary to take into consideration the data representativeness, and measurement accuracy and discreteness. The research future is industrial testing of the developed system of the automated control under the conditions of the real production. Moreover, the development of alternative nonlinear regulators based upon synergy, neural networks, and other approaches of computational intelligence is another actual problem. Nonlinearity; aperiodicity; nonstationarity; uncertainty (i.e. availability of incomplete and/or fuzzy information) of static and dynamic characteristics of operating procedures under the conditions of underground mineral mining are the basic difficulties. Use of minimax control (i.e. minimization of electricity consumption along with ore extraction maximization) in terms of "Water" channel will result in the predicted almost $4.3 \%$ increase in daily EE consumption. That will be compensated in full by the increased daily ore output. Use of control based upon optimum setting $123^{*}$ of (25) type will factor into the maintenance of the planned daily IORM extraction. Nevertheless, in this context the total expenditures, connected with EE consumption, will decrease by $16.23 \%$ owing to more rational distribution of ore-and water flows as well as to corresponding power consumption in terms of process stages.

\section{Conclusions}

Fuzzy logic has been applied to develop algorithms of functioning of ACS for electric power consumption of a standard iron-ore mine in terms of day parts. The algorithms are more favourable to compare with the available ones since the number of control influences is identified using availability of connections between the controlling parameters and the controlled ones as for the process stages of IORM extraction.

Fuzzy regulators to control EE consumption in a mine have been developed and modeled with the help of Fuzzy Logic Toolbox modulus of MATLAB computing environment. The regulators were developed basing upon a use of one, two, or three controlling influences of \{“Ore", "Water", and "Air" $\}$ sets, and two alternative approaches: minimum approach (according to two basic criteria) or optimum one (according to the setting). It has been determined that use of strategy one always results in $15-50 \%$ increase of daily ore output and EE consumption as well as $11-75 \%$ of corresponding expenditures. At the same time, potential income from IORM compensates in full the charges. Use of control based upon optimum settings (strategy two) results in 20-28\% decrease in expenditures connected with EE consumption in the context of the maintenance of the planned indices of IORM extraction.

Application of the proposed approaches will help implement the automated control of mine EE consumption in real time, and optimize expenditures connected with the EE consumption. Forward estimates demonstrate the potential to obtain extra revenue in terms of the current hourly tariff scale as for the iron-ore Kryvbas mines at the level of UAH 1.7-4.4 mln per day.

\section{Acknowledgements}

The authors express gratitude to employees of energy service of Kryvorizkyi Zalizorudnyi Kombinat PJSC for their engineering support while carrying out the experiments under the conditions of the Integrated Works mines and to the authorities of Kryvorizelectromontazh Ltd as the leading enterprise engaged in the design, modernization, and implementation of electric power supply systems for iron-ore production units of Kryvyi Rih iron-ore basin for their financial support in the paper publication.

\section{References}

[1] Vilkul, Yu., Azaryan, A., Kolosov, V., Karamanyts, F., \& Batareev, A. (2015). Suchasnyi stan zalizorudnoi haluzi, prohnoz rozvytku ta propozytsii. Kachestvo Mineral'nogo Syr'ya, 9-24.

[2] Babets, Ye., Melnikova, I., \& Grebenyuk, S. (2015). Doslidzhennia tekhniko-ekonomichnykh pokaznykiv hirnychodobuvnykh pidpryiemstv Ukrainy ta efektyvnosti ikh roboty $v$ umovakh zminnoi koniuktury svitovoho rynku zalizorudnoi syrovyny. Kryvyi Rih, Ukraina: NDGRI DVNZ "KNU".

[3] Sinchuk, I., Boiko, S., Baranovska, M., Kozakevich, I., Syomochkyn, A., Kalmus, D., Peresunko, I., Vinnik, M., Lokhman, N., \& Chorna, V. (2019). Brief commentaries on the problem of power consumption management at iron ore underground mines. Warsaw, Poland: Science.

[4] Sinchuk, I. (2018). Harmonization of modeling systems for assessing the electric-power consumption levels at mining enterprises. Mining of Mineral Deposits, 12(4), 100-107. https://doi.org/10.15407/mining 12.04.100

[5] Zakon Ukrainy "Pro rynok elektrychnoi enerhii" vid 13.04.2017 \#2019-VIII. (2017). Kyiv, Ukraina: VRU.

[6] Patterson, S.R., Kozan, E., \& Hyland, P. (2015). An integrated model of an open-pit coal mine: improving energy efficiency decisions. International Journal of Production Research, 54(14), 4213-4227. https://doi.org/10.1080/00207543.2015.1117150

[7] De Souza, E. (2015). Improving the energy efficiency of mine fan assemblages. Applied Thermal Engineering, (90), 1092-1097. https://doi.org/10.1016/j.applthermaleng.2015.04.048

[8] Muller, S.C., Hager, U., \& Rehtanz, C. (2014). A multiagent system for adaptive power flow control in electrical transmission systems. IEEE Transactions on Industrial Informatics, 10(4), 2290-2299. https://doi.org/10.1109/tii.2014.2315499

[9] Ivashchenko, V. (2005.) Teoretiko-metodologicheskie osnovy, metody i matematicheskie modeli upravleniya elektropotrebleniem promyshlennykh predpriyatiy. Vestnik $S G T U,(2), 100-113$.

[10] Liu, B., Wu, W., Zhou, C., Mao, C., Wang, D., Duan, Q., \& Sha, G. (2019). An AC-DC hybrid multi-port energy router with coordinated control and energy management strategies. IEEE Access, (7), 109069109082. https://doi.org/10.1109/access.2019.2933469

[11] Reyes-Chamorro, L., Bernstein, A., Bouman, N.J., Scolari, E., Kettner, A.M., Cathiard, B., \& Paolone, M. (2018). Experimental validation of an explicit power-flow primary control in microgrids. IEEE Transactions on Industrial Informatics, 14(11), 4779-4791. https://doi.org/10.1109/tii.2018.2802907

[12] An initiative of the risk response network. (2012). Global Risks, (7), 1-7. 
[13] Wu, T.-Y., Shieh, S.-S., Jang, S.-S., \& Liu, C.C.L. (2005). Optimal energy management integration for a petrochemical plant under considerations of uncertain power supplies. IEEE Transactions on Power Systems, 20(3), 1431-1439. https://doi.org/10.1109/tpwrs.2005.852063

[14] Tabart, Q., Vechiu, I., Etxeberria, A., \& Bacha, S. (2018). Hybrid energy storage system microgrids integration for power quality improvement using four-leg three-level NPC inverter and second-order sliding mode control. IEEE Transactions on Industrial Electronics, 65(1), 424-435. https://doi.org/10.1109/tie.2017.2723863

[15] Dasgupta, S., Mohan, S.N., Sahoo, S.K., \& Panda, S.K. (2013). Lyapunov function-based current controller to control active and reactive power flow from a renewable energy source to a generalized threephase microgrid system. IEEE Transactions on Industrial Electronics, 60(2), 799-813. https://doi.org/10.1109/tie.2012.2206356

[16] Stevanoni, C., De Greve, Z., Vallee, F., \& Deblecker, O. (2019). Longterm planning of connected industrial microgrids: a game theoretical approach including daily peer-to-microgrid exchanges. IEEE Transactions on Smart Grid, 10(2), 2245-2256. https://doi.org/10.1109/tsg.2018.2793311

[17] Zakharova, A. (1982). O zakonakh raspredeleniya vremeni bezotkaznoy raboty i vremeni vosstanovleniya elementov sistemy elektrosnabzheniya ugol'nykh razrezov. Sbornik Nauchnykh Trudov MEI, (7), 124-131.

[18] Li, S., Yu, X., Fridman, L., Man, Z., \& Wang, X. (2018). Advances in variable structure systems and sliding mode control - theory and applications. Studies in Systems, Decision and Control. https://doi.org/10.1007/978-3-319-62896-7

[19] Van Schuppen, J.H., \& Villa, T. (2015). Coordination control of distributed systems. Lecture Notes in Control and Information Sciences. https://doi.org/10.1007/978-3-319-10407-2
[20] Mohammadpour, J., \& Grigoriadis, K.M. (2010). Efficient modeling and control of large-scale systems. https://doi.org/10.1007/978-1-4419$\underline{5757-3}$

[21] Singh, S.N., Wen, F., \& Jain, M. (2019). Advances in system optimization and control. Lecture Notes in Electrical Engineering. https://doi.org/10.1007/978-981-13-0665-5

[22] Qi, R., Tao, G., \& Jiang, B. (2019). Fuzzy system identification and adaptive control. Communications and control engineering. https://doi.org/10.1007/978-3-030-19882-4

[23] Zhang, Y., Hong, M., Dall'Anese, E., Dhople, S.V., \& Xu, Z. (2018). Distributed controllers seeking an optimal power flow solutions using ADMM. IEEE Transactions on Smart Grid, 9(5), 4525-4537. https://doi.org/10.1109/tsg.2017.2662639

[24] Leonchikov, A. (2003). Nechetkoe modelirovanie $v$ srede MATLAB $i$ fuzzy TECH. Sankt-Peterburg, Rossiya: BHV-Sankt-Peterburg.

[25] Jin, H., Li, Z., Sun, H., Guo, Q., \& Wang, B. (2019). Coordination on industrial load control and climate control in manufacturing industry under TOU prices. IEEE Transactions on Smart Grid, 10(1), 139-152. https://doi.org/10.1109/tsg.2017.2733578

[26] Kupin, A., \& Senko, A. (2015). Principles of intellectual control and classification optimization in conditions of technological processes of beneficiation complexes. CEUR Workshop Proceedings, (1356), 153-160.

[27] Kupin, A., Vdovichenko, I., Muzyka, I., \& Kuznetsov, D. (2017). Development of an intelligent system for the prognostication of energy produced by photovoltaic cells in smart grid systems. EasternEuropean Journal of Enterprise Technologies, 5(8(89)), 4-9.

\section{Деякі аспекти розбудови схеми функціонування автоматизованої системи} керування електроенергопотоками підземних залізорудних підприсмств

\section{О. Сінчук, А. Купін, І. Сінчук, М. Рогоза, П. Плєшков}

Мета. Розробка схеми функціонування АСУ енергопотоками при інваріантності обсягів споживання електричної енергії та інверсії в потоковому часі доби енергопотоків гірничорудних виробництв для зменшення сегмента електроенергозатрат у собівартості видобутку залізорудної сировини (ЗРС).

Методика. На основі даних пасивного експерименту отримана статистика роботи залізорудних шахт. Далі із застосуванням нечіткої логіки визначено лінгвістичні терми необхідних технологічних параметрів, здійснені процедури фазифікації, логічного висновку і дефазифікації. Обумовлені принципи формування бази нечітких правил для можливості автоматизації прийняття рішень із застосуванням методики Мамдані. В результаті цього були синтезовані нечіткі регулятори і промодельована їх робота у середовищі програмного пакету MatLab. Основні результати моделювання представлені візуально за допомогою MS Excel.

Результати. Обгрунтовано систему критеріїв управління, визначені вектор стану об'єкту, основні інформаційні параметри, керуючі дії та збурення. Досліджено підходи для оптимізації процесу споживання електричної енергії на основі мінімаксних функціоналів, використання системи обмежень, обчислення раціональних уставок. Розроблено алгоритми автоматизованого управління із використанням декількох стратегій і критеріїв. Запропоновано принципи реалізації зазначених алгоритмів на основі використання нечіткої логіки (Fuzzy Logic).

Наукова новизна. Доведено працездатність нечітких систем управління енергопотоками шахт в умовах одноканального та багатоканального регулювання. Отримано основні аналітичні показники, які однозначно підтверджують достатню якість та ефективність застосування систем автоматизованого управління для підземного видобутку залізної руди.

Практична значимість. Запропоновано структурні схеми та засоби для практичної реалізації нечітких регуляторів у промислових умовах. Підтверджено розрахунковим шляхом, що застосування даних підходів дозволить реалізувати автоматизоване управління процесом шахтного енергоспоживання в умовах реального часу й оптимізувати витрати на спожиту електричну енергію.

Ключові слова: автоматизоване керування енергопотоками, Fuzzy Logic, система керування, тризонний тариф

\section{Некоторые аспекты построения схемы функционирования автоматизированной системы управления электроэнергопотоками подземных железорудных предприятий}

\section{О. Синчук, А. Купин, И. Синчук, М. Рогоза, П. Плешков}

Цель. Разработка схемы функционирования АСУ энергопотоками при инвариантности объемов потребления электрической энергии и инверсии в поточном времени суток энергопотоков горнорудных производств для уменьшения сегмента электроэнергозатрат в себестоимости добычи железорудного сырья (ЖРС).

Методика. На основе данных пассивного эксперимента получена статистика работы железорудных шахт. Далее с применением нечеткой логики определены лингвистические термы по необходимым технологическим параметрам, осуществлены процедуры фазификации, логического вывода и дефазификации. Обусловлены принципы формирование базы нечетких правил для возможности автоматизации принятия решений с применением методики Мамдани. В результате этого были синтезированы нечеткие регуляторы и промоделирована их работа в среде программного пакета MatLab. Основные результаты моделирования представлены визуально с помощью MS Excel.

Результаты. Обосновано систему критериев управления, определены вектор состояния объекта, основные информационные параметры, управляющие воздействия и возмущения. Исследованы подходы для оптимизации процесса потребления электрической энергии на основе минимаксных функционалов, использования системы ограничений, вычисления рациональных уставок. Разработаны алгоритмы автоматизированного управления с использованием нескольких стратегий и критериев. Предложены принципы реализации указанных алгоритмов на основе использования нечеткой логики (Fuzzy Logic). 
Научная новизна. Доказана работоспособность нечетких систем управления енергопотоками шахт в условиях одноканального и многоканального регулирования. Получены основные аналитические показатели, которые однозначно подтверждают достаточное качество и эффективность применения систем автоматизированного управления для подземной добычи железной руды.

Практическая значимость. Предложены структурные схемы и средства для практической реализации нечетких регуляторов в промышленных условиях. Подтверждено расчетным путем, что применение данных подходов позволит реализовать автоматизированное управление процессом шахтного энергопотребления в условиях реального времени и оптимизировать затраты на потребленную электрическую энергию.

Ключевые слова: автоматизированное управление энергопотоками, Fuzzy Logic, система управления, трехзонный тариф

\section{Article info}

Received: 4 December 2019

Accepted: 14 August 2020

Available online: 4 September 2020 